\title{
UNAUTHORIZED PRACTICE OF LAW: ARIZONA SUPREME COURT PROHIBITS MANY ACTIVITIES OF TITLE COMPANIES
}

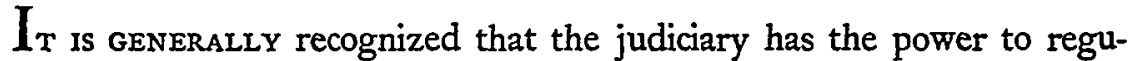
late the practice of law. ${ }^{1}$ The Arizona Supreme Court, in the recent case of State Bar of Arizona v. Arizona Land Title and Trust Co., ${ }^{2}$ exercised this broad judicial power by condemning as the unauthorized practice of law a wide variety of activities commonly engaged in by title companies and real estate brokers in that state.

The complaint alleged that title companies and real estate brokers acting through employee-attorneys and lay employees had regularly and continuously engaged in preparing, drafting, and formulating for their numerous customers various documents affecting title to real property and in giving legal advice regarding these land transactions. The Arizona court, in holding the challenged conduct constituted the unauthorized practice of law, formulated a declaratory judgment defining the practice of law and decreeing specifically what the defendants could ${ }^{3}$ and could not $\mathrm{do}^{4}$ in the future.

${ }^{2}$ For an analysis of the judicial power in this area, see Comment, $28 \mathrm{U}$. CHI. L. REV. I62 (1960). 45 CORNELI L.Q. 126, 129 (1959), contains a discussion of the majority and minority rules and the types of sanctions imposed by the courts. For an excellent survey of the remedies available to combat the unauthorized practice of law see Note, 62 Colum. L. Rev. 501 (1962).

290 Ariz. 76, 366 P.2d I (196I).

'The court specifically decreed that the defendants can engage in the following activities: "(a) draft and suggest the inclusion of clauses in any document affecting its fiduciary capacity, for its own protection as such fiduciary, when acting as a trustee, administrator, executor, subdivision trustee or other fiduciary; (b) prepare or draft any instrument relating to property in which the title company has an absolute or equitable ownership, or proposes to acquire such ownership thereby; (c) formulate and prepare policies of title insurance, and state the conditions or requirements to be met before it will issue a particular title insurance policy, and state its reasons for refusal to issue any particular title insurance policy; (d) furnish abstracts of title and similar information reports, without expressing opinions as to the validity or legal effect of documents or information contained or referred to therein; (e) transmit notices requiring strict performances and notices of forfeiture required to be served by it as a condition of delivery of any documents it holds in a collection escrow; (f) deliver to or file with any person or public body or officer, any document which it is specifically required to file or deliver under the terms of any instrument which designates it in a fiduciary capacity." Id. at i 5 .

'The court said that the defendants are engaged in the unauthorized practice of law when they: "(a) prepare by drafting or filling in blanks, deeds or conveyances of any kind, forms of notes, mortgages, satisfactions of mortgages, assignments of mort- 
In recent years there has been a surprising resurgence of litigation in the presumably well-settled area of unauthorized practice of law. One reason for this renewed litigation is the active role taken by the American Bar Association in bringing actions against various wellestablished lay groups allegedly "practicing law." Furthermore, ever-

gages, contracts for sale of real estate, or assignments thereof; (b) prepare, by insertion or filling in of blanks, customary or other forms of subordination agreements, outright or unconditional lease termination agreements, outright or unconditional assignments of leases, rental agreements, lien waivers, affidavits or completion of improvements, partial releases of mortgages, or deeds of patented mines; (c) prepare 'curative' instruments even in connection with title insurance or escrows; (d) draft, prepare or fill in blanks in applications to assign an assumption of leases of federal lands; assignments of state leases; forest permits or assignments or waivers thereof; restrictions or restrictive covenants affecting real property; (e) prepare, draft or fill in any other instruments not here enumerated affecting interests in or titles to real property, or creating or releasing burdens or encumbrances upon land; (f) draft, prepare or fill in bulk sales notices, affidavits or claims; modification, extension, water or party wall agreement; agreements of cancellation and termination other than of escrow agreements to which they are parties as escrow agents; administrators' or executors' deeds; amendments or restrictions; options, corporate resolutions; affidavits of termination of joint tenancy; instruments of deeds of dedication or creating easements or rights of way; consents to assignments; subdivision plats; wills, or any document or pleading designed or intended for presentation or submission to a court, board or commission, or a judicial or quasijudicial body or official; (g) draft trust agreements, subdivision or otherwise, (h) prepare documents relating to personal property, even when they intend to insure title to such property; (i) give advice concerning or explain the legal effect of transactions involving or affecting interests in or title to real property, or creating or releasing burdens or encumbrances upon land, including but not limited to subdivision trusts; (j) give advice concerning, or discuss the legal effects of clauses in wills or other legal instruments; (k) give advice concerning or discuss the legal effects or implications of tax legislation." Id. at 14-15.

27 UNaUthorized Practice News 7 (1961) tells of three suits in which the American Bar Association's Committee on the Unauthorized Practice of Law has been active. One suit is the instant case, one was State ex rel. Reynolds v. Dinger, 14 Wis. $2 d 193,109$ N.W.2d 685 (196I), discussed note 31 infra, and the third is an Indiana case not yet reported.

The American Bar Association's Committee on the Unauthorized Practice of $\mathrm{Law}$ has laid down two definite principles to guide local bar associations in bringing actions against lay groups for the unauthorized practice of law: " 1 . No prosecution of any form of unauthorized practice should be undertaken by a bar committee unless it can be clearly shown that such practice in the given case is resulting in injury to the public. 2. No proceeding should be instituted based solely on the economic interest of the bar." 26 A.B.A.J. 104 (1940).

Because of the strong stand taken by the bar, the lay groups attacked have fought back with tenacity. C. Armel Nutter, President of the National Association of Real Estate Boards, made a speech in Dallas, Texas, on Nov. 15, 1960, dealing with relations between brokers and the bar. The principal headline in the New York Times the next day, Nov. 16, 1960, was "Lawyers Scored by Realty Chief," the subhead said "President of Brokers Group Says Practices Opposed by Attorneys Will Continue." 
increasing complexities in the economic and social order have wrought changes in the type of unauthorized practice cases coming before the courts. Current litigation involves the widespread encroachment of large corporate enterprises into areas traditionally served by the lawyer. Thus, the policies enunciated in bygone eras require re-evaluation in terms of the present needs of society. The Arizona court undertook such a re-evaluation in the instant case by adopting a historical, ${ }^{6}$ yet analytical, approach in which it examined the role of the lawyer in modern society and concluded by reaffirming that "the practice of law" should be restricted to licensed practitioners. ${ }^{\text {? }}$

In deciding that the lawyer should continue to have an exclusive right to practice law, the court was faced squarely with the recurring problem of determining what constitutes "the practice of law." Conflicting definitions are often adopted ${ }^{9}$ and, even more seriously, courts

For an interesting account of this running battle between the realtors and the bar, see 27 UNAUthorized Practice News No. 1, p. I (1961).

'The court traced the history of the legal profession from its inception in ancient Greece through the Roman empire, the Middle Ages, medieval England, and then discussed its early difficulties in America. From an examination of this history it is seen that the policies behind the lawyer's exclusive right to practice law were promulgated and became crystalized at a time when the typical unauthorized practice case concerned a criminal action against a pseudo-lawyer or disbarred attorney accused of practicing law for a fee. For a history of the legal profession and an insight into how it gained an exclusive right to practice law, see generally PoLLOcK \& MAITLAND, THE History of ENGLish LaW (2d ed. 1898); Chroust, The Legal Profession During the Middle Ages: The Emergence of the English Lawyer Prior to 1400,31 NoTRE DAME Law. 537 (pt. I 1956). vom Baur, An Historical Sketch of the Unauthorized Practice of Law, 24 Unauthorized Practice News, No. 3, p. I (1958).

${ }^{7} 366$ P.2d at 8.

a "Research of authorities by able counsel and by this court has failed to turn up any clear, comprehensible definition of what really constitutes the practice of law. ... Each case must be decided upon its own particular facts." Arkansas Bar Ass'n v. Block, 230 Ark. 430, 434, 323 S.W.2d 912, 914, cert. denied, 361 U.S. 836 (1959). See Grand Rapids Bar Ass'n v. Denkema, 290 Mich. 56, 287 N.W. 377 (1939).

${ }^{\circ}$ One trend of thought would draw a distinction between the preparation of instruments and their presentation in court. See Atianta Title \& Trust Co. v. Boykin, 172 Ga. 437,157 S.E. 455 (1931), where the court held that the statute regulating the practice of law had reference to the practice before the courts only and a corporation could examine, certify, and guarantee titles to real estate requested by a customer. Cf. Arkansas Bar Ass'n v. Union Nat'l Bank of Little Rock, 224 Ark. 48, 273 S.W.2d 408 (1954). However, the majority view would appear to be that the practice of law "includes legal advice and counsel, and the preparation of legal instruments . . . by which legal rights are secured, although such matter may or may not be depending [sic] in a court." Eley $v$. Miller, 7 Ind. App. 529, 535, 34 N.E. 836, 837-38 (1893). See State Bar Ass'n of Conn. V. Connecticut Bank \& Trust Co., 345 Conn. $222,234-35$, 140 A.2d 863,870 (1958), where the majority view is well stated. See also In re Shoe Mfr's Protective Ass'n, Inc., 295 Mass. 369, 3 N.E.2d 746 (1936); 
tend to resolve unauthorized practice problems by definition alone. ${ }^{10}$ Yet, while it is important that a clear statement be formulated, a court cannot construct a definition which will always automatically distinguish those activities within the province of the bar from those properly conducted by the laity. ${ }^{11}$ Moreover, in trying to draw such a definitional line without stating reasons for its decision, a court would be making an unarticulated policy choice. In the instant case, the court correctly recognized the impossibility of formulating a precise definition that would include only those activities properly considered the "practice of law." After choosing a definition flexible enough for application in the myriads of differing situations that arise, ${ }^{12}$ the Arizona court was careful to articulate the reasons for its choice.

In concluding that a lawyer should have an exclusive, judicially protected right to perform the activities in question, the court carefully contrasted the title company-customer relationship with the attorneyclient relationship. The court felt that the profit motive of the title company and the loyalty of lay employees to the company were not conducive to the best protection of the customer's legal rights. ${ }^{13}$ When the company employee "fills in a form" his choice is dictated by what is advantageous for the company and not necessarily by what is desirable for the customer; likewise, when this employee advises on the legal effect of the document, the interests of the employer and not the customer may be uppermost in his mind. On the other hand, the strict fiduciary

In re Opinion of the Justices, 289 Mass. 607, 194 N.E. 313 (1935); Detroit Bar Ass'n v. Union Guardian Trust Co., 282 Mich. 216, 276 N.W. 365 (1937); Adler, The Bar's Campaign Against Unauthorized Practice, II ARK. L. REv. 320 (1957).

${ }^{10}$ Courts tend to divide their decisions into two questions: 1 ) Is the corporate fiduciary acting primarily for itself or for others, and 2) assuming the fiduciary is acting for the holders of the beneficial interest, do its acts involve the performance of a "legal service." See 45 CoRNeIL L.Q. 126 (1959); 43 MinN. L. Rev. 827 (1959).

${ }^{21}$ Note, 36 Notre DaMe Law. 374, 375 (1961).

12 "We believe it sufficient to state that those acts, whether performed in court or in the law office, which lawyers customarily have carried on from day to day through the centuries must constitute "the practice of law." 366 P.2d at 9. For the same definition stated in a more detailed form see $i d$. at 14 .

13 "The relationship betweeu title company employees and company customers bears none of the characteristics of the attorney-client relationship envisioned in this Canon [referring to Canon of Professional ETHics 15 that requires a lawyer to give complete devotion to the interests of his client]. The evidence indicates unequivocally that the primary objective of the title companies is the business of insuring titles and that, therefore, the employees' concern with the legality of transactions leading to a policy of title insurance must be primarily from the point of view of the company's rights and obligations rather than that of the parties to the transaction." Id. at 9. See Note, 36 Notre DaMe LAw. 374, 375 (1961). 
character of the attorney-client relationship is designed to give the utmost protection to the client. ${ }^{14}$ The lawyer is governed by canons of professional ethics that require him to observe the highest standards of conduct and maintain complete devotion to the interests of his client; consequently, the advice he gives will best effect the objectives of the client. Therefore, the Arizona court felt strongly that the "monopoly"15 that would result from its granting to lawyers the exclusive right to perform the challenged activities was designed for the protection of the public $^{16}$ rather than to aid the attorney financially..$^{17}$

The same conflict of interest problem inherent in the title companycustomer relationship also arises with respect to attorneys employed by the title company. The defendants argued that since these lawyers are subject to the same judicial control and discipline as other licensed practitioners, ${ }^{18}$ they should be allowed to perform legal services for a corporation's customers. However, the court in the instant case held that the corporation-employed lawyer who does legal work for the corporation's customer is faced with a clear conflict of interest. ${ }^{19}$ One

\footnotetext{
"As stated by one court, "A dual trust is imposed on attorneys at law. They must act with fidelity both to the courts and to their clients. They are bound by canons of ethics which are enforced by the courts. The relation of an attorney to his client is pre-eminently confidential. It demands on the part of the attorney undivided allegiance, a conspicuous degree of faithfulness and disinterestedness, absolute integrity and utter renunciation of every personal advantage conflicting in any way directly or indirectly with the interests of a client." State Bar Ass'n of Conn. v. Connecticut Bank \& Trust Co., 145 Conn. 222, 234, 140 A.2d 863, 870 (1958).

15 "The problem of unauthorized practice of law is a problem of using the processes of the law to define and protect a monopoly." Llewelleyn, The Bar's Troubles, and Poultices-and Cures?, 5 LAW \& CONTEMP. Prob. Io 4 (1938).

${ }^{16}$ The public policy behind the prohibition against practice of law by laymen is that ". . . upon matters affecting one's legal rights, one must have assurance of competence and integrity and must enjoy freedom of full disclosure, with complete confidence in the undivided allegiance of one's counselor in the definition and assertion of the rights in question." Beach Abstract \& Guaranty Co. v. Bar Ass'n of Arkansas, 230 Ark. 494, 501, 326 S.W.2d 900, 903 (1959). "Protection of the public is set at naught if laymen who are not subject to court supervision are permitted to practice law." Gardner v. Conway, 234 Minn. 468, 478, 48 N.W.2d 788, 795 (I95I); cf. Lowell Bar Ass'n v. Loeb, 315 Mass. 176, 52 N.E.2d 27 (1943): Washington State Bar Ass'n v. Washington Ass'n of Realtors, 41 Wash. 2d 697, 701, 25I P.2d 619, 621 (1952).

${ }_{17}$ As was stated in Hulse v. Criger, 336 Mo. 26, 37, 247 S.W.2d 855, 857 (1952), "The duty of this court is not to protect the Bar from competition but to protect the public from being advised or represented in legal matters by incompetent or unreliable persons." See Beach Abstract \& Guaranty Co. v. Bar Ass'n of Arkansas, supra note r6. ${ }^{18} 366$ P.2d at ro.

10 "The title company lawyer is confronted with at least three separate clients: the title company, and each of its customers involved in the transaction. It is difficult to
} 
court has called it an "evasion which the law will not tolerate"20 when a corporation that cannot practice law directly ${ }^{21}$ hires an attorney-employee to do so indirectly. ${ }^{22}$

A principal argument of title companies, trust companies, and similar organizations, and one raised in the instant case, is that the practice of preparing, drafting, selecting, and filling in of legal forms and documents has become incidental to their business. Defendants have maintained that to enjoin all their challenged practices where they are not actually representing themselves ${ }^{23}$ would work great hardship on the business involved and would not further the public interest because they are fully competent to perform these activities. ${ }^{24}$ Courts have reached

conceive how the title company attorney can maintain the proper professional posture toward each, when at least some of their interests may conflict." Id. at I I. See CANON of Professional Ethics 35.

${ }^{20}$ State Bar Ass'n of Conn. v. Connecticut Bank \& Trust Co., 145 Conn. 222, 23536,140 A.2d 863,871 (1958).

${ }^{21}$ It is clear that a corporation cannot "practice law." See People v. People's Trust Co., 180 App. Div. 494, 167 N.Y. Supp. 767 (1917); Note 32 So. CaL. L. REv. 425,427 ( 1959 ). Artificial creations such as a corporation or association cannot meet the prerequisites necessary to become a licensed practitioner. State Bar Ass'n of Conn. v. Connecticut Bank \& Trust Co., 145 Conn. 222, 140 A.2d 863 (1958); See Annot. 69 A.L.R.2d 394 (1958).

However, if the definition of the practice of law is restricted to appearance in court, then a corporation can in effect do what the lawyer does out of court. See Atlanta Title \& Trust Co. v. Boykin, 172 Ga. 437,157 S.E. 455 (1931), note 9 supra.

${ }^{22}$ See People v. Merchants' Protective Corp., I89 Cal. 53 I, 538-39, 209 Pac. 363, 366-67 (1922); Pioneer Title \& Trust Co. v. State Bar of Nevada, 74 Nev. 186, 326 P.2d 408, 4II (1958); In re Co-operative Law Co., I98 N.Y. 479, 483 ; 92 N.E. 15, 16 (1910); Judd v. City Trust \& Savings Bank, I33 Ohio St. 81, 12 N.E.2d 288 (1937); 66 AM. BAR Ass'N REP. 268 (194I). For a flagrant example of conduct that would probably be held contempt of court in any jurisdiction, see People v. People's Stock Yards State Bank, 344 Ill. 462, I76 N.E. 901 (I93I), where a bank's attorneys performed almost every kind of legal services for the bank's customers, the bank collecting the fees.

Another problem that plagues the attorney-employee is that the corporation often advertises that it has lawyers on its staff. 366 P.2d at II; In re Rothman, I2 N.J. 528 , 97 A.2d 621 (I953).

${ }^{23}$ The Arizona Court conceded the right of defendants to act "in propria persona" where they have an "interest" in the actual subject matter of the transaction, but merely having a pecuniary interest in the transaction because of the prospect of gaining a fee is not a sufficient "interest" to allow self representation. 366 P.2d at 9. See a strong statement limiting the defendant's right to represent themselves in Carter v. Trevathan, 309 S.W.2d 746, 748 (Ky. 1958). The North Carolina Supreme Court has held in a very recent decision that a lay officer, agent, or employee may prepare corporate legal documents if the corporation has a primary interest in the transaction. State v. Pledger, 257 N.C. 634,127 S.E.2d 337 (1962).

24 ' $\mathrm{It}$ is an essential part of the real estate man's competence to know when the matter of drafting an instrument is so complex as to call for legal counsel, or to know when it is beyond his own experience. But it is obvious that if, on the verge of writing 
diametrically opposed views on whether identical practices are incidental to the business and therefore lawful, or are the unauthorized practice of law. ${ }^{25}$ Factors that tend to influence a court's decision on the question of whether the practices are incidental to the business are whether compensation is paid for the services, ${ }^{28}$ whether the practices involve

every apartment lease, or rent receipt, every contract to purchase, every listing of a property for sale, every commitment to loan, every mortgage and every deed, the transaction unust halt till an attorney comes in and prepares the paper, there will entail an almost immeasurable waste in time, in cost, in difficulty of getting any meeting of minds, and there might well arise a socially undesirable reluctance on the part of people generally to undertake the ownership of a commodity so bound with red tape and tortuous circumambulations. And upon the real question of public policy involved, I believe we should have lessened rather than strengthened the likelihood of reaching in the average case the instrument that would work best and fit best the need of the situation. We shall have attomeys deluged with trivialities, but we shall have each individual user of real estate limited perforce to such legal experience in the field of real estate as he himself individually can afford to employ. We shall not have the leaven that is now at work bringing to the ordinary small transaction, through standard forms and related discussions, a city-wide or national real estate experience focused through employment of counsel who have given a life-time of study to real estate law." Nelson, Drafting of Real Estate Instruments: The Problent From the Standpoint of the Realtors, 5 LaW \& Contemp. Prob. 57, 63 (1938). See Ingham County Bar Ass'n v. Walter Neller Co., 342 Mich. 214, 69 N.W.2d 713, 721 (1955).

Those realtors who are members of the National Association of Real Estate Boards, numbering 67,000 out of 500,000 people directly involved in the selling of real estate, subscribe to a Code of Ethics which prohibits them from practicing law. According to the realtors, this means that they may fill out forms regularly used in the course of their business, but cannot draw instruments not related to the conduct of a real estate transaction. The American Title Association has no similar provision in its Code of Ethics. Note, 36 Notre DaMe LAw. 374, 376 (196x).

${ }^{25}$ One line of cases holds that the practice of fllling in blanks and drafting simple legal instruments has become such an integral and essential part of defendants' business that they cannot be termed the practice of law. See Merrick v. American Security \& Trust Co., 107 F.2d 271 (D.C. Cir. 1939); Cowern v. Nelson, 207 Minn. 642, 647, 290 N.W. 795, 797 (1940); New Jersey State Bar Ass'n v. Northern New Jersey Mortgage Associates, 55 N.J. Super. 230, 150 A.2d 496 (1959); Bar Ass'n of Tenn. v. Union Planters Title Guaranty Co., 326 S.W.2d 767 (Tenn. App. 1959), cert. denied (Tenn. Sup. Ct., June 5, 1959); State ex rel. Reynolds v. Dinger, 14 Wis. $2 d$ 193, I09 N.W.2d 685, 69x (1961).

Another group of cases holds that the practice of filling in blanks does constitute the practice of law. See Arkansas Bar Ass'n v. Block, 323 S.W.2d 912 (Ark. 1959); Agran v. Shapiro, 127 Cal. App. 2d 807, 817, 273 P.2d 619, 625 (1954); Keyes Co. v. Dade County Bar Ass'n, 46 So. 2d 605 (Fla. 1950); Illinois State Bar Ass'n v. Schafer, 404 Ill. 45, 87 N.E.2d 773 (1949); Clark v. Reardon, 231 Mo. App. 666, 104 S.W. 2d 407 (1937); Washington State Bar Ass'n v. Washington Ass'n of Realtors, 41 Wash. 2d 697, 25 1 P.2d 619 (1952). For a good summary of the cases in this area and the differing results reached see Annot., 53 A.L.R.2d 788 (I957).

20 See New Jersey State Bar Ass'n v. Northern New Jersey Mortgage Associates, 16r A.2d 257, 265 (N.J. 1960). The court in Hexter Title \& Abstract Co. v. Grievance Committee, 142 Tex. 506, 179 S.W.2d 946, 952 (1944), observed that the drafting of legal instruments was an inducement to a prospective customer to employ the title 
simple or complex questions of law, ${ }^{27}$ and whether there is a special public necessity because of peculiar circumstances. ${ }^{28}$ In the instant case, the court considered all of these factors and concluded that even if the disputed activities might be considered concomitants of the title insurance business, which was doubtful, they were still the practice of law, and the public welfare forbids such practice except by independent licensed attorneys. ${ }^{29}$

The defendants further asserted that the practices challenged have in a sense become authorized by long-standing custom..$^{30}$ A recent Wisconsin Supreme Court case seems to adopt this argument in a four to three decision. ${ }^{31}$ However, the Arizona court dismissed this contention,

company to insure his title and that the practice must pay or it would be discontinued. The court in Paul v. Stanley, 168 Wash. 371, 12 P.2d 401 (1932), said it was not the purpose of the legislature to protect the person who pays nothing for legal advice from incompetency on the part of the person doing the work; however, this view was overruled in Washington State Bar Ass'n v. Washington Ass'n of Realtors, 4I Wash. 2d 697, 251 P.2d 619 (1952), where it was pointed out that the same harm results whether the non-lawyer was paid or not. See Annot., 53 A.L.R.2d 788, 804-07 (1957), for a listing of cases where the giving or not giving of compensation has been important.

${ }^{27}$ Some courts say the drafting of simple instruments does not constitute the practice of law if incidental to a lawful business. See Gardner v. Conway, 234 Minn. 468, 48 N.W.2d 788 (1951); Cowern v. Nelson, 207 Minn. 642, 647, 290 N.W. 795, 797 (1940); State ex rel. Reynolds v. Dinger, 14 Wis. 2d 193, 109 N.W.2d 685 (r96r); Annot., 53 A.L.R.2d 788 (1957). The classic refutation of this distinction is made by Pound, J.: "I am unable to rest any satisfactory test on the distinction between simple and complex instruments. The most complex are simple to the skilled, and the simplest often trouble the inexperienced." People v. Title Guarantee \& Trust Co., 227 N.Y. 366, 379, 125 N.E. 666, 670 (1919) (concurring op.). See People v. Lawyers Title Corp., 282 N.Y. 513, 27 N.E.2d 30 (1970); Washington State Bar Ass'n v. Washington Ass'n of Realtors, supra note 26.

${ }^{28}$ The court in Conway-Bogue Realty Investment Co. v. Denver Bar Ass'n, 135 Colo. 398, 312 P.2d 998 (1957), candidly admitted that the challenged activities were the practice of law, but said these activities could not be labeled as unauthorized because of public necessity for the services in an area with a scarcity of lawyers. To reach this holding the court had to overlook one Colorado statute and override another. The decision was criticized in II OKLA. L. REv. 356, 358 (1958); 30 RocKY MT. L. REv. 94 (1957).

${ }_{20}^{20} 366$ P.2d at $11-12$. See note 16 supra.

80 "Business is not the outgrowth of the practice of law. The practice of law is the outgrowth of business." People v. Jersm, 101 Colo. 406, 412, 74 P.2d 668, 670 (1937). "What constitutes the emcrgencies and the exigencies of business in large measure always have depended, and always will depend, on the custom and practice of those who carry on the country's business, and within reasonable limits such customs and practices should, indeed must, be recognized." Id. at 413, 74 P.2d at $67 \mathrm{x}$.

${ }^{31}$ "From the very beginning, the custom of the real estate broker has been to use the forms readily procurable such as those now approved and standardized in sec. 235.16, Stats. Of course a violation of the law does not attain legality by lapse of time. On 
wryly observing that "this is tantamount to saying We have been driving through red lights for so many years without a serious mishap that it is now lawful to do so." "32 The court further stated that its. function was to prevent future harm as well as to redress past injury, and therefore there could be no prescriptive right to practice law. ${ }^{33}$

The State Bar of Arizona case thus appears to be the most thoroughgoing, well reasoned opinion on the subject of the unauthorized practice of law as it relates to large business concerns. The Arizona court carefully considered the specific practices challenged and at the same time contributed an excellent study on the general problem, articulating policy factors that will have wide application. The case demonstrates, however, that both the legal profession and lay groups can advance persuasive arguments in unauthorized practice cases. Because of the overriding public necessity of guaranteeing that the needs and rights of the private citizen will be served and protected, it would seem that costly litigation is often not the best solution to the problem of corporate intrusion into areas traditionally served by the lawyer. In some instances, voluntary agreements between bar and lay groups have demonstrated that peaceful, practical solutions are possible. ${ }^{34}$ How-

the other hand the acquiescence of the bar and the courts in a practice for some one hundred years may be persuasive that at least the practice has not been unauthorized. Otherwise, it may be supposed that the courts would have found it out and would not have shirked a duty to abolish it." State ex rel. Reynolds v. Dinger, 14 Wis. 2d 193, $\longrightarrow$, 109 N.W.2d 685, 691 (1961). The majority seemed unsure of its own opinion. It concluded that, "When we consider that such practices should be discontinued it will be time for us to use our power. It is not required now." Id. at, 109 N.W.2d at 692.

The dissentiug opinion of Hallows, J., was strougly critical of the majority's position. "Acquiescence for a long period of time does not change the nature of the practice complained of. The majority opinion further states that had the practice been unauthorized, it might be supposed this court would have found it out by itself and would not have shirked a duty to abate the offense. This court does not employ investigators to ferret out unauthorized practices of law. We are not an investigatory body. When such matters are brought :o our a:t:ntioa, we take notice of them...." Id. at -, 109 N.W.2d at 693. See Bar Ass'n of Tenn. v. Union Planters Title Guaranty Co., 326 S.W.2d 767 (Tenn. App. 1959), cert. denied (Tenn. Sup. Ct., June 5, 1959), which like the Dinger case holds the challenged activities are incidental to defendant's business. Again there was a stroug dissent, and there have been critical reviews of the case. See 13 VAND. L. REv. 574 (1960); 34 ST. John's L. REv. 353 (1960). For a general discussion of the subject see Skiba, The Completion of Deed Forms by Real Estate Brokers, 44 MARQ. L. REV. 519 (196I).

32366 P.2d at 13 .

s. Id. at 13 .

s4 An excellent example of cooperation between bankers and the bar is reported in 32 So. CAL. L. REv. 425 (1959). "A workable solution to the difficult problem of 


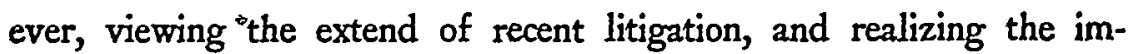
portance of the economic aspects involved, it would be unwise to assume that the battles being waged in the courts will not continue..$^{35}$

determining wbat services banks and trust companies may perform has been found in California. The State Bar of California and the California Bankers' Association have . adopted a treaty defining what services banks and trust companies may perform without invading the sphere of the bar, and which services are forbidden. Also, a standing committee has been established to handle all grievances. As a result, most of the "unlawful practice" problems are handled through the cooperation of the State Bar and the Bankers' Association, even though acts not covered by the treaty frequently are involved. Since the line between permissible and forbidden conduct in this area is so difficult to establish, a treaty advising banks and trust corporations as to which activities are proper has great value in reducing litigation and in harmonizing all of the interested groups." Id. at 429. See Adler, supra note 9, at 323, where similar agreements including collection agencies, insurance adjustors, banks, trust companies, publishers, realtors, certified public accountants, life insurance underwriters, and life insurance companies are discussed.

${ }^{33}$ An informed public is necessary before unauthorized practices can be stopped by anything but court action, and yet "The serious disadvantage of the unauthorized practice committees' crusade is that it lacks the sympathy of the public. The conviction of laymen and even some lawyers that the goal sought is to prevent the loss of legal business and fees is likely to withstand the most public spirited language. Sanctions imposed on disbarred attorneys or obviously incompetent practitioners are supported by all groups; but where competent specialists, rather than petty poachers, are included in the intruder class, the tendency is to equate the bar's negative struggle with trade union featherbedding practices. Whereas organized association efforts have had great success in raising and preserving the prestige of the legal profession generally, it is not at all clear that the unauthorized practice campaign has achieved similar results. Since the effectiveness of the profession must be largely proportionate to the public's impression of it, it appears that a fresh approach may be called for." 45 CoRnel. L.Q. 126,134 (1959).

One writer contends that, "More urgent, however, is the need for educating the lawyers themselves. Far too few understand what constitutes unauthorized practice, what can be done about it, what is being done, and why it is not only their right, but their duty, to do something about it." Adler, supra note 9, at 323. 